\title{
$\begin{array}{lllll}\mathrm{P} & \mathrm{R} & \mathrm{O} & \mathrm{S} & \mathrm{A}\end{array}$
}

REI N A L D O M O R A E S

\section{EXCERTO DO CAPÍTULO 2 DO ROMANCE MAIOR QUE O MUNDO}

Ó tu que vens de longe, ó tu que vens casada...

Como fui me lembrar desse verso antigo, de um soneto lido numa antologia dum velho poeta gaúcho que ganhei há milênios duma poetinha gaúcha que zanzava por São Paulo mascateando em bares e antessalas de cinema de arte e teatros a brochurinha de poemas compostos e impressos por ela mesma. Não lembro dos poemas, mas lembro da poeta. Vinte e poucos anos, baixinha mignon, com aquele sotaque porto-alegrense que sempre achei tão suave e sensual. Era também grande fă do Strumbicômboli, essa menina, fato que nos aproximou. Ela tinha um nome, que eu, Fanfarrão Amnésio, não lembro agora. Sei que a gaúcha tinha um namorado em Porto Alegre, outro strumbicomboliano devoto.

Ele tá lá agora? - perguntei pra ela de gaiato.

Tá.

Ótimo. Tá em Porto, tá alegre.

Ela riu e me deu esse livrinho do 'Ó tu que vens casada' que trazia na bolsa. Passei a bagana que a gente fumava pra ela, abri numa página qualquer e li em voz alta o soneto. Ela disse: 'Só que eu não sou casada, só namorada'. Corrigi: 'Ó tu que vens namorada... mas que o namorado tá em Porto Alegre, bem longe daqui...'. A gente não tinha trepado ainda, o que não demorou a acontecer. Aí tive uma surpresa das mais surpreendentes, por sinal. Bom, sempre é uma surpresa a primeira vez que se trepa com alguém. Nesse caso, a surpresa era o grelão da mina instalado numa 
buceta cabeluda donde emanavam uns feromônios de brócolis refogados no alho, com ligeiro retroacento de sardinha fresca. Era vegetariana a... Teka! Esse é o nome dela. Se lembrei do cheiro da buceta, como não me lembraria do nome de sua dona? Nunca tinha visto uma coisa daquelas e nunca mais vi nem senti nada igual. Que puta grelo aquele: uma piroquinha tesa no meio do matagal de pentelhos. Dei umas lambidas, ensaiei um boquetinho clitoriano ali, mas achei meio esquisito. Ela achou ótimo. Acabou que eu me concentrei foi na xota mesmo, um aquífero vaginal. Nunca fodi uma buceta tão lubrificada. Finalizei a transa, daquela primeira vez, comendo ela por trás, na xota, mas sem contato com o maxigrelo. Aquele grelão, sei lá, é o tipo da coisa que deve demorar um tempo até você se acostumar. Quanto tempo, só o namorado dela lá em Porto Alegre pode responder. Ela parecia não esquentar muito com isso nem com nada. A gente tinha bebido, fumado maconha e só queria se divertir e, se possível, gozar.

Um dia, depois de uma noite intensa de copos e fodas, acordei na minha cama vazia de mulher. A Teka tinha deixado um bilhete em cima do travesseiro no qual dizia ter tido um 'sonho forte' naquela noite e que, por isso, acordou cedo e se mandou pra rodoviária. Deu saudade do namoradinho, decerto, misturada com alguma culpa. Ele devia ser mesmo o cidadão mais preparado pra dar conta daquele grelôncio. Bá, tchê. Bye-bye.

Lembrei do nome do poeta daquele verso da mulher casada que vem de longe: Alceu Valmosy. Seria uma ode ao adultério, aquele soneto? Se eu tivesse um smartphone, checaria isso agora mesmo no Google. Ôpa: tem uma lan house logo ali. E se eu fosse lá tentar caçar esse poema do gaúcho Valmosy? Tempo tenho de sobra. Pour quoi pas? Bora lá.

Tem umas cinco baias, só uma ocupada. Me instalo na baia três e clico no Google Chrome. Boto Alceu Valmosy no campo de busca e — ha! — não éValmosy, é Wamosy. Quase acertei. Ainda bem que esse Google não se intimida com imprecisões ortográficas. A garota do caixa me olha com precavida curiosidade. Que tanto esse maluco fala nesse estranho aparelho enquanto navega pela internet? 


\section{$\begin{array}{lllll}\mathrm{P} & \mathrm{R} & \mathrm{O} & \mathrm{S} & \mathrm{A}\end{array}$}

A ver, a ver... Taqui: Alceu Wamosy nasceu no fim do século XIX e morreu em 1923 dum tiro que levou numa revolução que teve por lá. Antigamente os gaúchos é que estavam sempre dando ou levando tiro. Hoje são os cariocas. Logo encontro o soneto da mulher casada que surge de repente na vida do poeta. Ele diz pra ela que 'a minha alcova tem a tepidez de um ninho'. Ou seja, vamos lá pro meu ninho, baby, dar umas bimbadas tépidas antes do nascer do sol e do corno do teu marido acordar. Daí, 'quando a luz do sol dourar, radiosa, essa estrada sem fim, deserta, imensa e nua, podes partir de novo, ó nômade formosa!. É isso aí, gata, faz um bidêzinho rápido e volta logo pra casa, que tu mora longe pra caralho e... peraí. Que história é essa de nômade?

Quá-quá-quá: não é 'ó tu que vens casada'. É 'ó tu que vens cansada.' É cansada, não casada. Li e decorei errado a porra do verso do gaúcho. Vai ver foi porque a gauchinha corneava alegremente o namorado dela, que, por sua vez, vai saber o que aprontava lá pelos pampas na sua ausência. Mas pode ser que a edição que ganhei de presente contivesse um pastel gráfico. Porra, passei mais de vinte anos citando errado o verso do gaúcho, cujo sobrenome eu também errava. A musa do poeta é uma nômade cansada que vem de longe, não uma biscatinha comprometida que mora na perifa e veio sortá a franga e o grelão na cama tépida do poeta bacanudo, a exemplo do que a minha gauchinha de ocasião viera fazer em São Paulo, nos anos 90. Levantei feliz do computador. Eu tinha corrigido um erro histórico da maior importância: Ó tu que vens cansada...

\footnotetext{
Reinaldo Moraes tem 69 anos. Nasceu e vive em São Paulo. Escreveu os romances Tanto faz, (Brasiliense, 1981; reeditado pela editora Azougue em 2003 e pela Companhia das Letras em 2011), Abacaxi (LPఠ M, 1985; reeditado pela Companhia das Letras em 2011), A órbita dos caracóis (Companhia das Letras, 2003; com várias reediçôes), Pornopopéia (Objetiva, 2009); Maior que o mundo (Alfaguara, 2018); os contos de Umidade (Cia. das Letras, 2005), a novela infantil Barata! (Cia das Letrinhas, 2007) e relatos de viagem em Estrangeiros em casa - Uma caminhada pela selva urbana de São Paulo (Editora Abril, 2004, com fotos de Roberto Linsker).
} 